International Journal of Social Sciences and Humanities
Available online at http://sciencescholar.us/journal/index.php/ijssh
Vol. 2 No. 1, April 2018, pages: $134 \sim 146$
e-ISSN: 2550-7001, p-ISSN: 2550-701X
http://dx.doi.org/10.29332/ijssh.v2n1.104

\title{
Intervention of Social Work in Political Participation of Women in Forming Process of Neighborhood Councils of Canton Portoviejo
}

\author{
(D) crossmark \\ Monica Liliana Velez Zambrano a, Mercedes De Los Angeles Cedeno Barreto b, \\ Tatiana Katiuska Moreira Chica c,
}

Article history: Received 10 September 2017, Accepted in revised form 20 February 2018, Approved 20 March 2018, Available online 27 March 2018

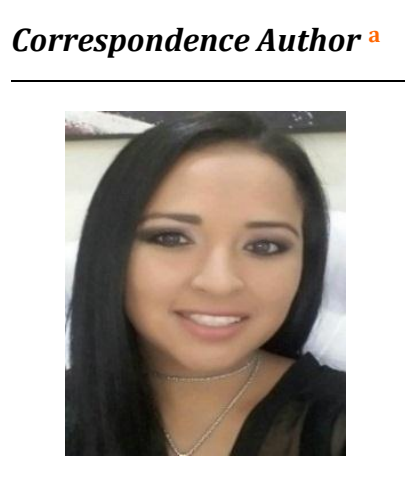

Keywords

Neighborhood councils;

Participation;

Social intervention;

Social worker;

Women;

\begin{abstract}
With globalization, it has become evident that there are still differences in women's participation in political development, despite the process of change, equality and equity implemented for several years, the greater participation of men in relation to the woman, have been excluded in some spaces within society for a long time. The political participation of women continues to be a great challenge in Ecuador's contemporary society. The processes carried out have not achieved the inclusion of women in the issues of political representation. As a whole, the causes may be ignorance, omission, and of course this machismo that predominate even on the subject; without leaving of side the little processes of investigation on the subject, that are sporadic, and more in the subject of the considered policy only for the masculine gender. The current challenge is the empowerment, education, preparation and training of both men and women on the issue of equality, inclusion and social participation of all in the different mutual areas with emphasis on the political, economic and social aspects of development and well-being of people, guaranteed in the Constitution of Ecuador and the objectives of Good Living.
\end{abstract}

e-ISSN : 2550-7001, p-ISSN : 2550-701X ${ }^{\odot}$ Copyright 2018. The Author. SS Journals Published by Universidad Técnica de Manabí. This is an open-access article under the CC BY-SA 4.0 license (https://creativecommons.org/licenses/by-sa/4.0/) All rights reserved.

\section{Contents}

Abstract

1. Introduction

2. Research Method

a Graduate of the Universidad Técnica de Manabí, Portoviejo Ecuador

b Universidad Técnica de Manabí, Ecuador, South America

c Universidad Técnica de Manabí, Ecuador, South America 


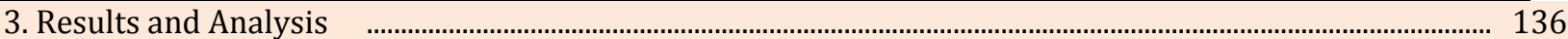

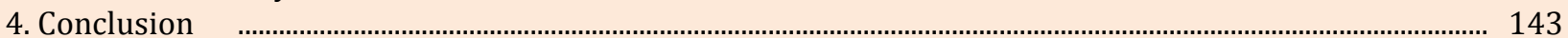

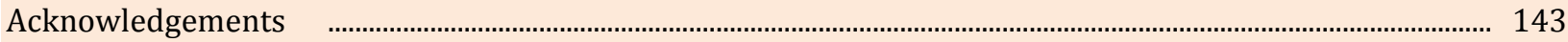

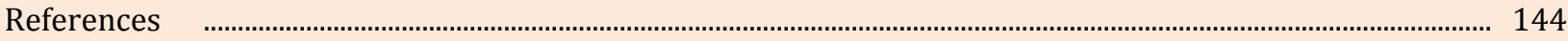

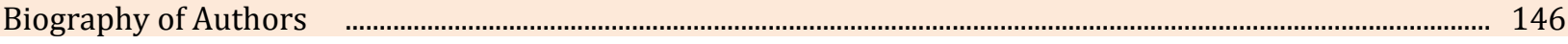

\section{Introduction}

The woman has been an object from the beginnings of the civilization, of a segregationist treatment in all the scopes of the social and deprived life, is a subject that has been treated in many places at the global level. Even today, for many, the word "woman" is a reference to discriminatory treatment, because it is only thought that men are capable of correctly performing their obligations to society.

In the Arab world, the law encourages the inequality of women, research has assessed this problem ranging from conflicts to the crisis, reaching serious consequences in different areas: political, social, economic and cultural [1]. Studies conducted on the subject show that Arab countries have the highest rates of female illiteracy and low levels of women's labor integration; and on the other hand, a marked marginalization of female participation in the public and private productive and reproductive spheres. In countries such as Morocco, this situation has changed with the introduction of new concepts, such as coresponsibility. The equality of women with respect to men is enshrined and divorce is established by mutual consent [2].

In spite of the efforts that have been made by the United Nations with the proclamation of the principle of non-discrimination based on sex, in such a way that at present it is an indisputable precept of international law, it appears for the first time in the Charter of Nations of United Nations and in the Universal Declaration of Human Rights of 1948 [3]. Later it is reiterated in the international pacts of civil and political rights and of economic, social and cultural rights, adopted by the United Nations in 1966. [18]

The struggle of women organized for the recognition and guarantee of their rights has had to question the very definition of human rights and insist on the specific weight of the will. In short, it has required demonstrating in a continuous and reliable way, that women are human beings and as such, endowed with rationality and will to exist [3]. In Mexico women have not been recognized (not only unpaid) for centuries, women continue to be victims of a series of prejudices that prevent them from accessing the same salaries, benefits, and job security as men, in a construction of society Mexican, where women have twice the participation in social actions with respect to men [4]. According to this author, many women from the popular sectors of Mexico have been educated to work in the domestic space, being excluded from access to an education that can help them improve their income, with wider educational gaps when they are indigenous women and of religious minorities such as Protestants. [19]

In the rest of Latin America, this vision has changed despite the fact that there is still a long way to go. Currently, women are inserting themselves into these issues, because they have had to fight for political participation without exclusion. Women around the world have freed themselves to ensure that their voice and participation in any field are seen by society and demonstrate that a successful job can really be achieved. The leader Montonero Eloy Alfaro in the deployment of his policy was also concerned for the first time in Ecuadorian republican life, to free women from the bonds of the conservative past and their dependence on man [5], in addition to promoting education public for girls, opened certain state offices for female work, as happened in telegraphs and emails, as well as in certain secretarial or assistantship tasks in public assistance and in ministries. He even bequeathed several women: for example, as early as July of 1895 , Eloy Alfaro bequeathed Aurelia Palmieri so that, in recognition of his outstanding studies, he would continue to develop them in higher education. It was a policy that awoke serious social resistance, in a country that was not accustomed to granting women a role other than that of the home. Naturally, this feminine promotion exasperated the more traditionalist clergy, who always stood out for reinforcing segregationist ideas against women [5].

In the $21^{\text {st }}$ century, the questioning struggles of the patriarchal order continue under the leadership of women's movements that have generated important social gains towards inclusion, equity, and gender equality. Women fought for equality of rights and recognition of the leading role they have played throughout history to achieve their goal. In Ecuador, from the Constitution of Montecristi in 2008, article 35

Zambrano, M., Barreto, M., \& Chica, T. (2018). Intervention of social work in political participation of women in forming process of neighborhood councils of canton portoviejo. International Journal Of Social Sciences And Humanities (IJSSH), 2(1), 134-146. doi:10.29332/ijssh.v2n1.104 
states: "Older adults, girls, boys and adolescents, pregnant women, persons with disabilities, persons deprived of their liberty and those suffering from catastrophic illnesses or of high complexity, they will receive priority and specialized attention in the public and private spheres. The same priority attention will be received by people at risk, victims of domestic and sexual violence, child abuse, natural or anthropogenic disasters. The State will provide special protection to people in a situation of double vulnerability "[6], [3], [2], these elements have caused positive changes in what to do about Ecuadorian women. [20]

Later in the constitutional text itself, Article 70 states: "The State shall formulate and implement policies to achieve equality between women and men, through the specialized mechanism in accordance with the law, and incorporate the gender approach into plans and programs, and provide technical assistance for its mandatory application in the public sector "and article 160 states:" Persons aspiring to military and police career will not be discriminated against for their entry. The law will establish specific requirements for cases in which special skills, knowledge or abilities are required [6], members of the Armed Forces and the National Police will be subject to the specific laws that regulate their rights and obligations, and his system of promotions and promotions based on merit and with criteria of gender equity. Their stability and professionalism will be guaranteed...

In Ecuador, the Constitution protects the right to gender equality to hold public office, thus evidencing the changes framed in the principle of parity in electoral candidatures, instances of direction and decision in the public sphere, administration of justice, control organisms and in political parties. This work aims to describe the intervention of social work in the political participation of women in the process of forming the Barriales councils of the Portoviejo canton in the year 2017.

\section{Research Method}

The research methodology is of a descriptive and transversal nature, so that, in an objective and verifiable manner, the collection of detailed information that describes the situation of women in the social and political environment of a Neighborhood Council is achieved, comparisons are made and evaluations, which then make up the idea of the reality studied. The study is of a quantitative-descriptive nature, with primary data, transactional in the collection of information, micro-sociological in its sample coverage. The fields of study are politics and society. The population is composed of all the women leaders of the Neighborhood Councils and given the nature and quantity of the probabilistic sample, it was not necessary to apply the Larry and Murray equation.

The technique of the survey and the interview was applied, which allowed approaching reality from the point of view of the actors involved in the work. The results obtained will allow us to describe the women who are part of the political process reporting the current situations in which they are immersed, being the protagonists of this context.

\section{Results and Analysis \\ Women in politics}

The General Assembly of the United Nations adopted a resolution on the participation of women in politics [7]: "Women continue to be largely marginalized from the political sphere throughout the world, often as a result of laws, practices, discriminatory gender attitudes and stereotypes, low levels of education, lack of access to health care services and because poverty affects them disproportionately. "

Gender discrimination in this region is marked by issues such as religion, persistent cultural values based on macho ideas and the submission of women [8], poverty and multi-ethnic enclaves, as has already been pointed out. Along with this, the deficit and precarious employment, the scarce access to economic resources, such as the possession of the land, are shown as structural aspects that prevent progress in the reduction of inequalities.

Political participation has been considered for a long time through its most common form of expression, people seeking to practice in politics have proposals and programs established at a time, in which they can become elected or assigned by society through a popular election, so that the elect can meet the needs presented by citizens in a particular place. Political participation becomes cumulative so that those who carry out an action tend to perform others more frequently, due to the fact that there are more activities to be carried out in societies that present problems, which can affect the decisions of the government. The political participation of women continues to be a challenge for Ecuadorian society, they are now visible 
actors and have claimed female participation. This is why the commitment will always be to act with transparency, fairness, equity and inclusion of everyone from any area where a woman is in politics.

In Ecuador, public policies have been implemented in which political participation is promoted without any exclusion [9]. Therefore, men and women are included in the struggle for the promotion of a just and equitable society, in which the from both sides. The percentage distribution of electors and electors by sex from the 2009 sectional elections to those held in 2014 has been maintained in both electoral processes. Figure 1 shows this behavior in the reference years.

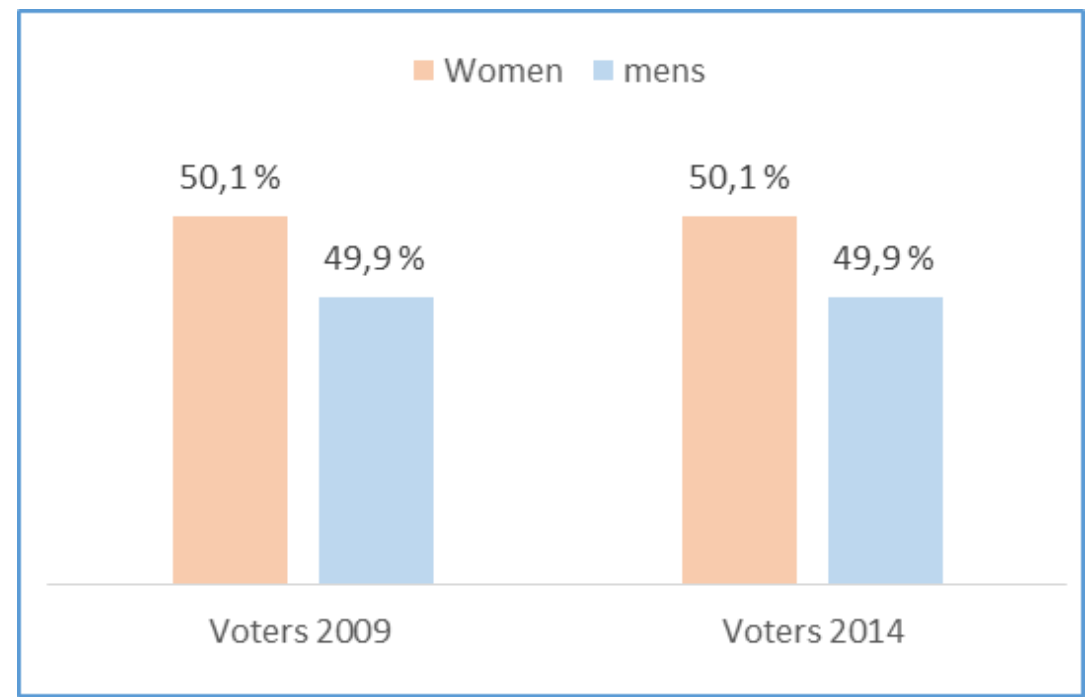

Figure 1. Electoral participation by gender (2009 - 2014)

Source: National Electoral Council, 2014

In the graph of the previous figure it is observed that there are no significant differences between the electors and the electors; but when the differences between candidates and main candidates are analyzed, as well as substitutes, the difference is noted, which can be clearly seen in figure 2 . For the case of the main candidates, women occupy a lower percentage and for substitutes occupy a greater percentage. percentage. So you can notice the effect of discriminatory traits for women to occupy main positions

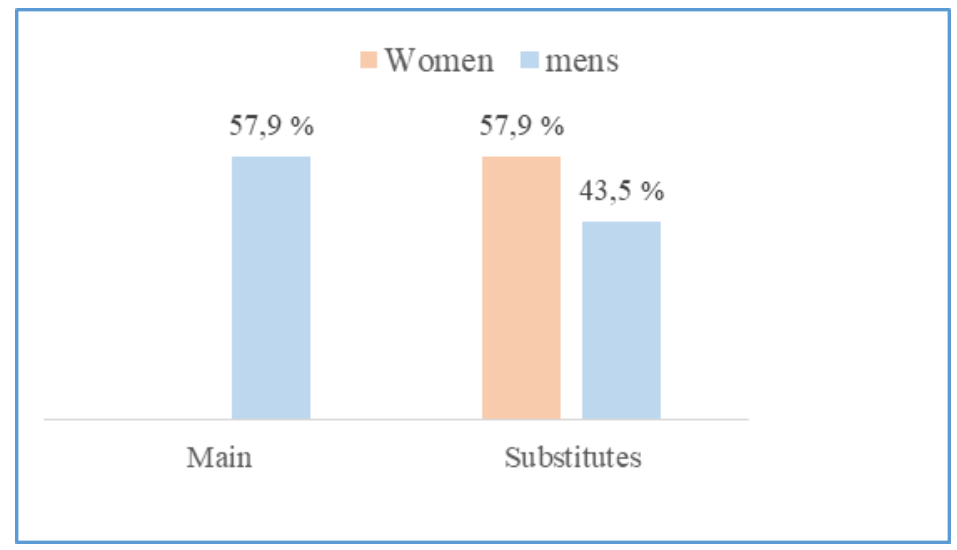

Figure 2. Distribution of main and alternate positions between women and men Source: National Electoral Council

Zambrano, M., Barreto, M., \& Chica, T. (2018). Intervention of social work in political participation of women in forming process of neighborhood councils of canton portoviejo. International Journal Of Social Sciences And Humanities (IJSSH), 2(1), 134-146. doi:10.29332/ijssh.v2n1.104 
Figure 3 shows the distribution of the candidates and candidates according to dignity and sex at the national level of the National Electoral Council, being able to appreciate that the female sex is discriminated against to favor the male sex.

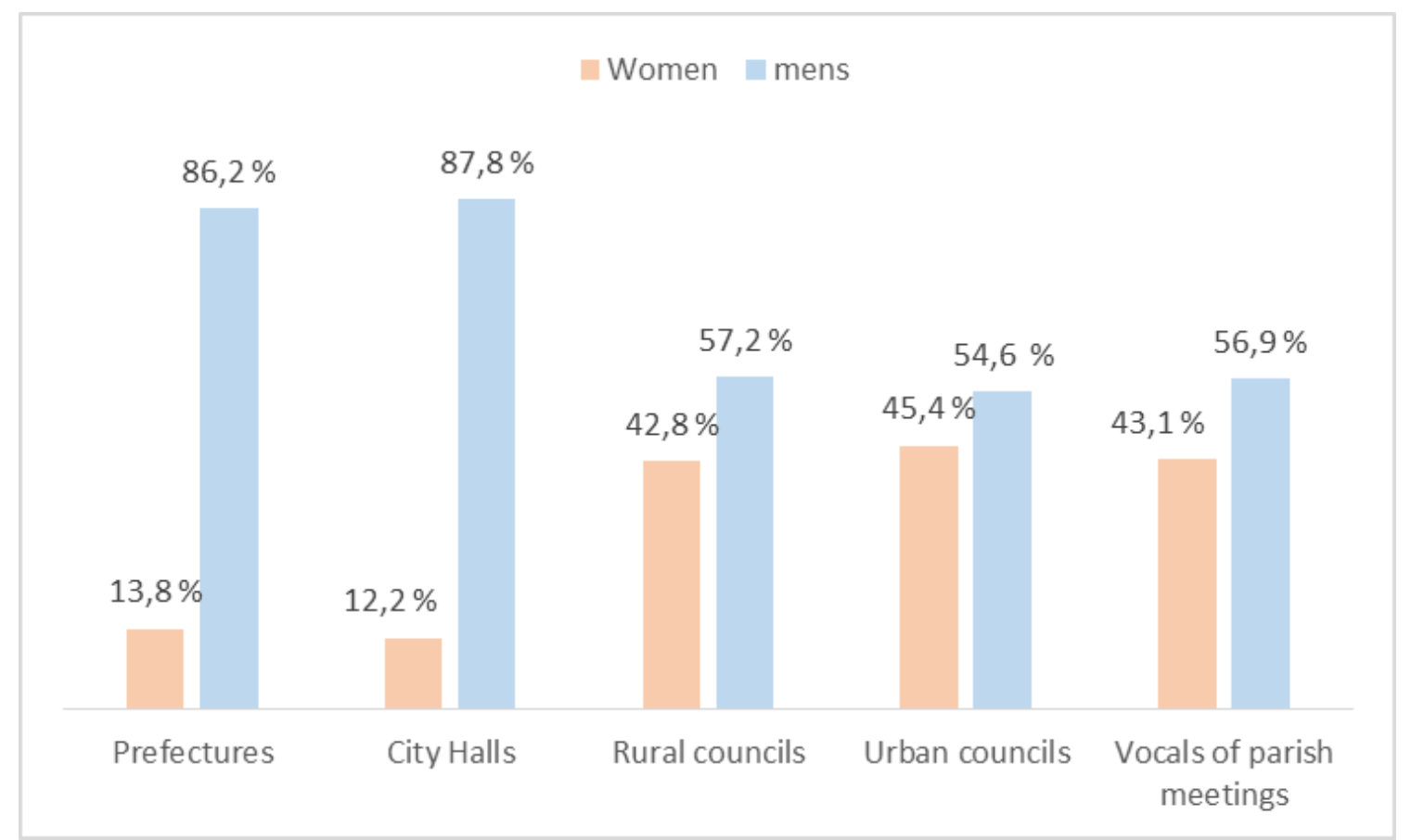

Figure 3. Candidates and candidates according to dignity and sex at the national level Source: National Electoral Council

In the graph of the previous figure, it is possible to notice that the positions of mayoral and prefecturelevel are more marked the difference and that in the lower levels the feminine presence is becoming more noticeable.

These results can be seen in the research carried out at the neighborhood level, where it has been working intensively and with constancy so that gender equality is carried out within the public policies that exist in the country, although there is still ground to be traveled in the awareness for that men and women can exercise their rights in fair conditions and rights, contributing and enhancing their own development and that of society. In the sectional elections of Ecuador in 2014, 25.7\% turned out to be women elected in the different dignities [9]. According to the results, it can be seen that at the level of prefectures and town halls the difference is overwhelming for men in relation to women, but in the urban and rural councils and the members the situation was better, noticing an exponential line in favor of the gradual increase of the presence of women elected in the different dignities. Figure 4 shows the percentage reached by women elected, noting that at least at the parish meetings there are already significant values 


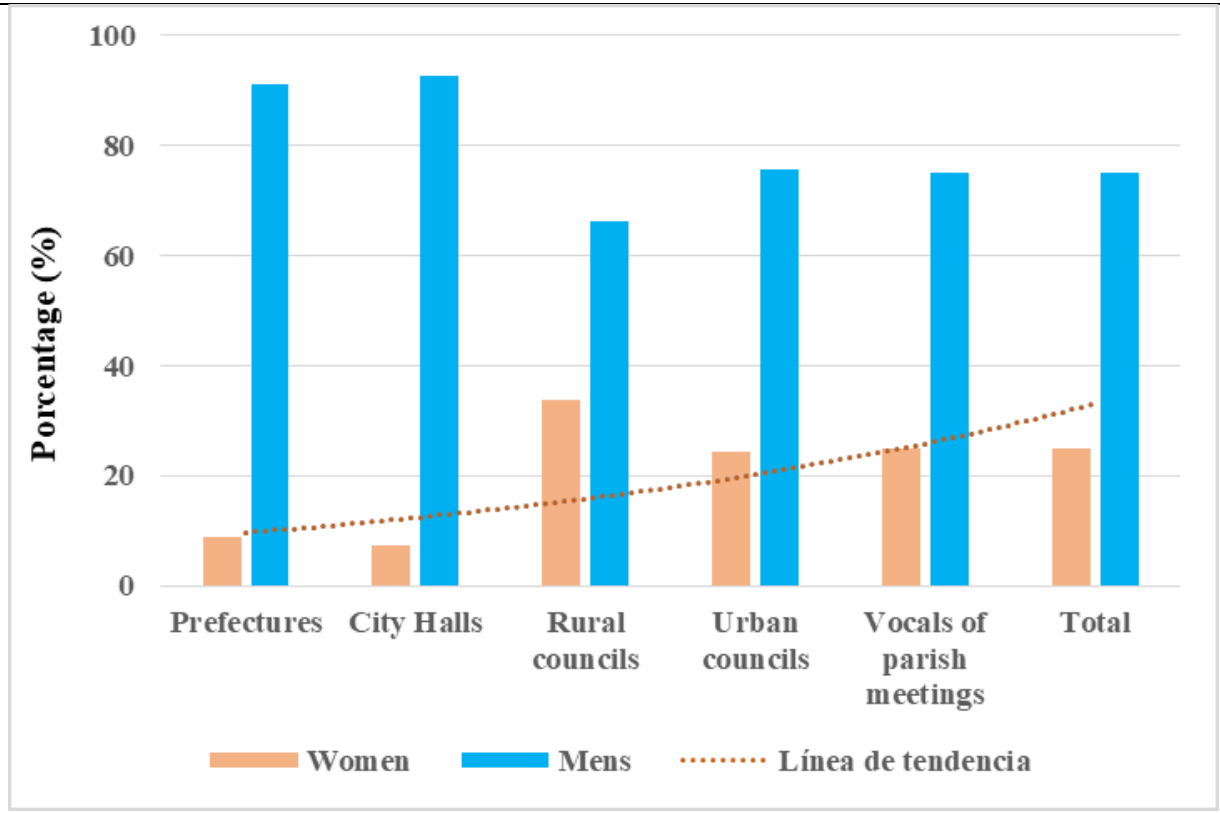

Figure 4. Percentage reached by women elected in the sectional lessons of the year 2014 Source: National Electoral Council

Especially in the province of Manabí during the elections of 2014, 28\% turned out to be women elected in the different dignities [10], slightly above the national average. However, it can be seen that at the level of prefectures and town halls, the difference is equal to the national average. In the urban and rural councils, as well as the boards, the situation was better, noticing an exponential line that marks a trend in favor of the gradual increase in the presence of women elected in the different dignities. Figure 5 shows the percentage reached by women elected in the province of Manabí.

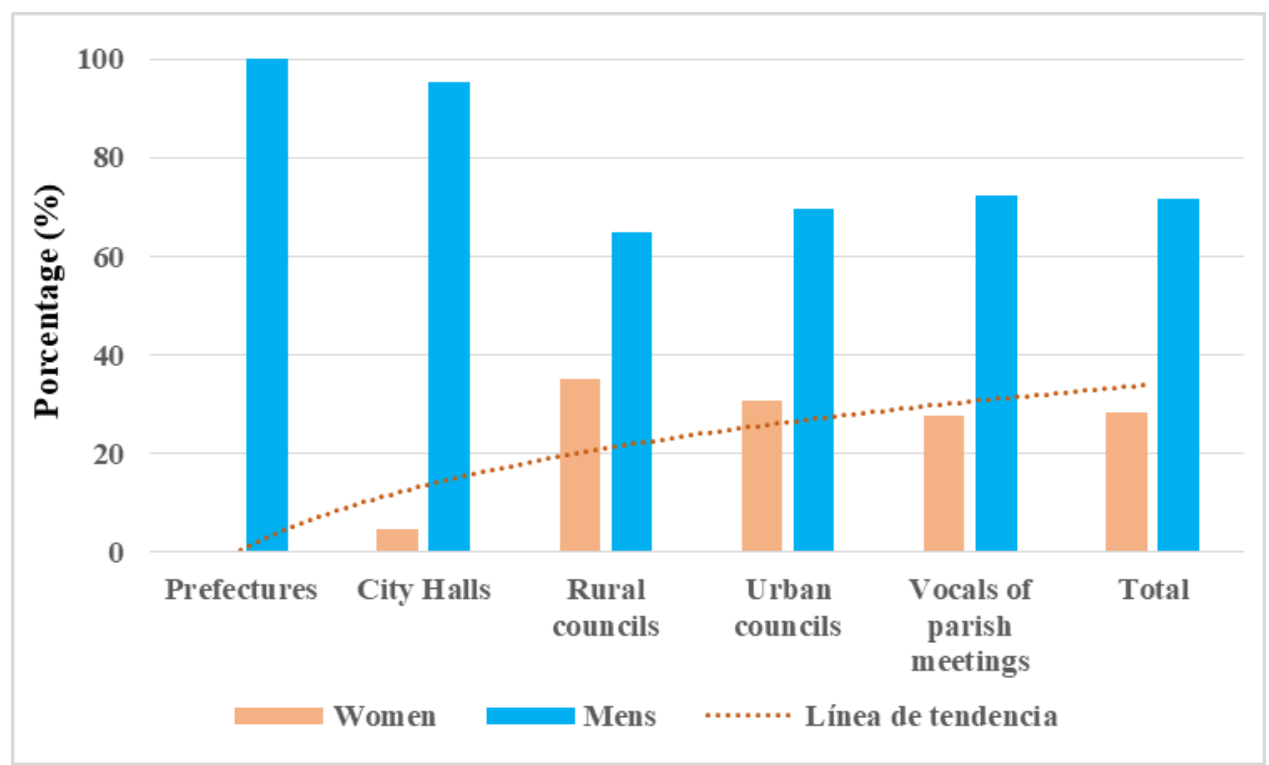

Figure 5. Percentage reached by women elected in the province of Manabí in the sectional lessons of the year 2014

Source: National Electoral Council

Zambrano, M., Barreto, M., \& Chica, T. (2018). Intervention of social work in political participation of women in forming process of neighborhood councils of canton portoviejo. International Journal Of Social Sciences And Humanities (IJSSH), 2(1), 134-146. doi:10.29332/ijssh.v2n1.104 


\subsection{Women's political participation at the neighborhood level}

Before beginning the analysis proposed in the research, the concept related to the neighborhood councils will be defined, which according to the methodological guide of neighborhoods and parishes [11], states that urban neighborhoods and parishes are recognized as basic units of citizen participation in Decentralized Municipal or District Autonomous Governments.

The communes, communities, and precincts will be considered as basic units for citizen participation within the Decentralized Autonomous Governments and in the National Decentralized Planning System. These are democratically elected through a general assembly of the neighborhood or parochial urban delegates permanently at the respective government level. At this level, the participation of women is a necessity for the achievement of equity, although it must be perfected to face the multiple obstacles that reality poses, a long way to go so that men and women can exercise their rights with equity by contributing and enhancing their own development and that of society.

\subsection{Neighborhood tips}

According to UNESCO [12], the neighborhood councils are a mechanism of participation in a canton in force since 2010. Have served as an ideal framework for leading the power of the people in terms of making decisions, within the framework of a certain number of inhabitants, in a direct way they have a leading role, the process of forming a list is applying parity and thus achieving the materialization of the inclusion policy.

Despite this the leading role of women is not as visible and they continue to manifest different actions that discriminate the management capacity and also the reputation who are exposed by municipal employees and the same community that demands attention without taking note that the neighborhood councils are only a channel for the authority to know what the citizens need.

The neighborhood leadership has cataloged in previous years only to seek its own benefit, considering that at present there are laws that formalize each neighborhood council as established, by then of citizen participation and social control and the Organic Code of Territorial Organization, Autonomy and Decentralization [13]. The Neighborhood Council is the most advanced form of social organization that can occur among the inhabitants of a neighborhood or citadel, to assume the real exercise of citizen power, in order to participate in a leading role in decision-making, planning and management of public affairs "[12], [13].

According to articles, 306 and 307 of the COOTAD, urban neighborhood and parish councils are organs of citizen representation before the decentralized municipal or district autonomous governments. Other institutions such as the National Electoral Council and the CPCCS also participate in the formation of neighborhood councils, demanding each one of them the parity between the conformations of its members, besides the work plan. Being actively in action capacity leads to the empowerment of the citizens so that there is an active cooperation within the different localities, generating a link between institutions and communities. Each representative is from the same neighborhood, taking care of the needs of their sector.

The communes, communities, and precincts have be considered as basic units for citizen participation within the Decentralized Autonomous Governments and in the National Decentralized Planning System at the respective government level. Neighborhood councils are necessary within each community because, thanks to these organizations, the residents can make their needs known through the representatives to the authorities.

\subsection{Inclusion as a policy}

According to studies conducted by the Inter-American Development Bank [14], it is argued that the central issues of the debate related to women on democracy, implies going beyond the absence of formal prohibitions or impediments to doing so. Ecuador is a democratic country, each citizen has freedom of expression, although recognition of inequalities is true, we must also recognize that the complexities existing in society have been changing day by day; many of the women also discriminated against themselves by thinking that they could not emphasize in this social context, which harmed them for several years.

The process of inclusion in Latin America, especially in Ecuador, which was the first country where women voted, had the power to make decisions for itself exercising a right as every citizen [14]. Here is how the This issue was later taken up again, in times of suffragist, focused mainly on the right to choose and, 
much later, almost at the end of the 20th century, women's rights were included, where women have the same right before the law than men.

\subsection{The social worker and the rights of women}

The professional nature of social work prevents him from abstracting from the problematics associated with gender discrimination and the sociocultural consequences that derive from it. The International Federation of Social Workers (FITS) defined at its Assembly in Montreal in July 2000, that the profession of social work promotes the change of society, the resolution of problems in human relations and the strengthening and liberation of the people to increase welfare. With theories about human behavior and social systems. Social work intervenes in the points where people interact with their environment. In this way, the principles of Human Rights and Social Justice are fundamental for social work [15].

Social work and women's rights are, therefore, two interconnected and complementary realities. The concept and models to achieve gender equity are not a panacea nor a simplifying recipe for complex social intervention processes, but they can be an approach that, in a transversal sense, guides the interventions of social workers in function of to achieve the levels of social equity desired between men and women.

The work of social work focuses on reducing the effects of poverty and improving the relationships that allow raising the living conditions of many people, and not only help the individual, but fight for social justice in a climate of community cooperation, working to eliminate racism, discrimination based on sex, religion, xenophobia and other social ills. They stand out for their performance as pioneers and innovators, developing their activity in a complex climate where other professionals do not prefer to arrive, however, their creative function of knowledge, has been little recognized and for years, the profession has had a role without much transcendence [16].

For its part, the essence of social work in terms of gender equity refers to promoting the ability of women to face tasks in new unexplored scenarios for them. In this regard, it is necessary to encourage optimism, the adventurous spirit, courage, self-understanding, humor, the ability to work hard and the ability to relate to men in a climate of respect and consideration. Under this approach, the environment is the main motivator for the deployment of women's capacities to face their role in conditions of parity with men [17]. When analyzing the starting point of social work in the interest of gender equity, important differences. They can be noted since social work consists of an intervention based on the knowledge of a problem or difficulty, which has its center of action in the person, where it acquires significance the sum of problems and difficulties that arise. In this way, professional attention focuses and prioritizes the problems of women from the angle of gender discrimination.

The information offered by the investigation of the case constitutes the starting point for the elaboration of the diagnosis. In this case, the intervention of social work has been sought, as a reliable ally for the support in the generation of adequate personal strategies that allow the woman to face the difficulties derived from the discrimination. The social work professional depending on the specific case and the particular social conditions where the work of the woman had were carried out has designed the action plan. In this sense, the dysfunctions that have were presented define the possibilities for personal development. Likewise, the resources that count are the knowledge, the skills of the professional and the social network that can serve as support. The qualified professional intervention of the worker or social worker is focused on reducing the effects of discrimination against women and the negative personal and social consequences that result from it, in this way social work initiates the process of transformation based on the problems that arise in the community, long before the discriminatory conflict takes its first consequences.

\subsection{Case study Portoviejo municipality}

As part of the investigation, a survey has was conducted of the 15 women who participate in politics in the neighborhood councils, aimed at knowing the different occupations, obligations, and rights that people have within the political context. In this way the percentage that it exists in the political participation of women in the Portoviejo Canton; On the other hand, it was possible to analyze the political participation of women in the neighborhood councils of the urban zone of the Canton.

It was found that $21,1 \%$ of the positions of presidents and presidents of the neighborhood councils are occupied by women, which marks an important majority of men occupying these positions. Of the 15 women

Zambrano, M., Barreto, M., \& Chica, T. (2018). Intervention of social work in political participation of women in forming process of neighborhood councils of canton portoviejo. International Journal Of Social Sciences And Humanities (IJSSH), 2(1), 134-146. doi:10.29332/ijssh.v2n1.104 
who hold positions of neighborhood presidents, three are parochial, belonging to San Pablo and March 12 and Andrés de Vera. Figure 6 shows the graphic relationship on female participation, occupying the position of presidents and presidents of neighborhood councils.

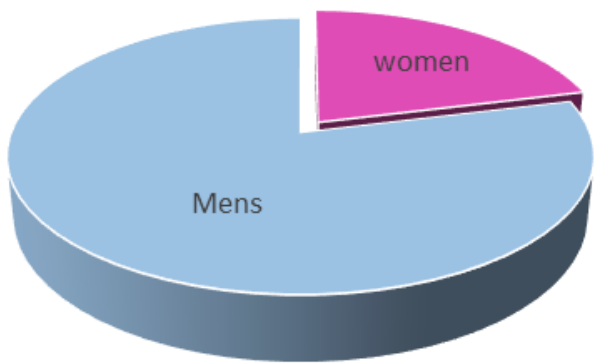

Figure 6. Participation of women in the positions of presidents and presidents of neighborhood councils in the canton of Portoviejo

Source: Members of the Neighborhood Councils of Portoviejo

The fundamental function of women as president of a Barrier Council is socio-organizational, being the community representation body of the lowest hierarchy in the political scale. The investigation made it possible to determine that the women who participate in politics are a consequence of a change that has occurred at present, and its objective is to generate significant transformations within the radius of parochial action.

The greatest achievements, challenges of women in political participation. In the neighborhood councils in Portoviejo, is that they are visible in all areas of popular election processes; where they must face the patriarchal reminiscences that still persist, promoting proposals that benefit the change towards greater political equity through forums, exchange of experiences with other neighborhoods; as well as promoting the permanent process of building citizen power. In the investigation, it was possible to determine that the average age of the women who participate in the neighborhood policy is 50 years, the average of children is four between females and males. The graph of Figure 7 shows the employment relationship of the respondents, where it was found that women workers predominate.

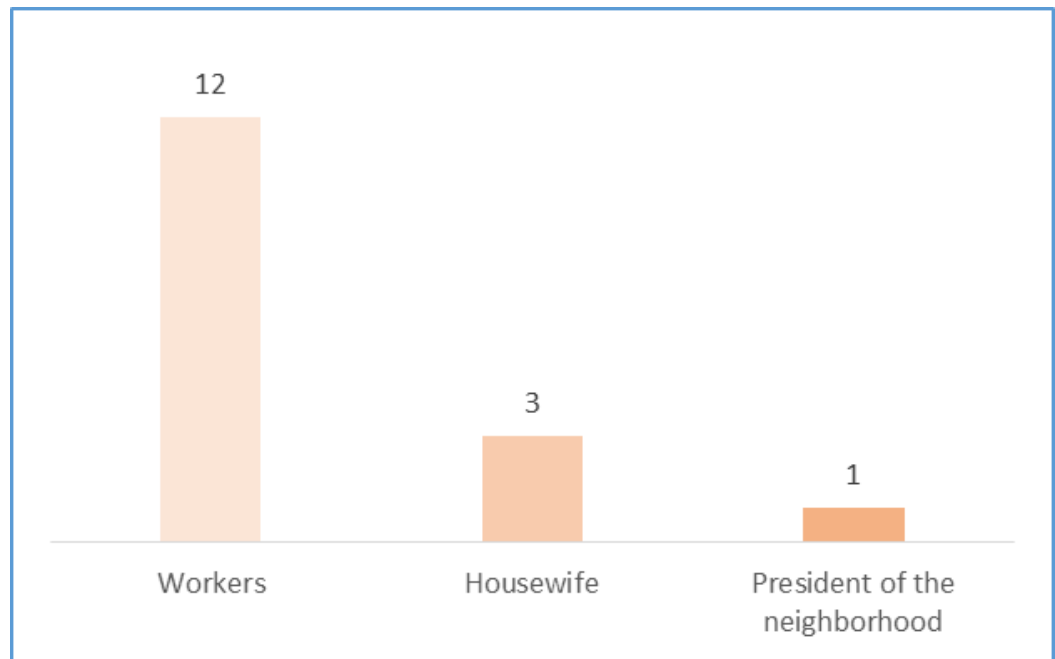

Figure 7. Relation of the employment of the surveyed women Source: Members of the Neighborhood Councils of Portoviejo 
It can be observed that only in one case does the occupation correspond to the position of neighborhood president, which shows that the insertion of women in politics is currently a challenge in each of the sociopolitical spaces. In spite of the advances that the country has experienced, where there are regulations that motivate women to participate in all political processes; there are still barriers that make it difficult for women to empower themselves of their rights and take advantage of their management skills.

One of the biggest challenges that social work currently was related to the identification, cultural improvement and empowerment of women leaders who, for lack of an adequate level, are unable to access political positions and dignities. Currently, some of these women have excluded from political life, suffering marginalization and rejection by those who direct each of the sectors, causing psychological and social upheavals that even affect the family life of these people. It is important that social workers take ownership of this problem, make it their own and applying the methodologies of social work, guides are implemented and an entire ethical movement is deployed aimed at guiding these women leaders for their personal development and that they can deploy all its capabilities for the benefit of society. Currently, several cantonal institutions have taken the first step to facilitate training for those who lack it, giving opportunities for them to acquire knowledge and strengthen their qualities as social leaders

\section{Conclusion}

The study made it possible to corroborate that Ecuador has been one of the first Latin American countries to visualize the importance of women in politics, but despite this it has been demonstrated that, in the last years of elections, men have had the primacy, problem that is visualized up to the neighborhood levels in the Portoviejo Canton.

Currently, a valuable potential of social leaders is being wasted, which, for reasons of cultural level and preparation, are excluded from the political life in the territory. Social workers can appropriate the flags of struggle for gender equity in the political life of the territory, playing the main role, aimed at identifying, preparing and preserving women with natural leadership skills, with the ability to develop a genuine and original role of social orientation of the popular masses for the benefit of the political life of the province.

Zambrano, M., Barreto, M., \& Chica, T. (2018). Intervention of social work in political participation of women in forming process of neighborhood councils of canton portoviejo. International Journal Of Social Sciences And 


\section{References}

1. Pérez Nasser, E. (2007). Las mujeres árabes en las mil y una noches: feminismo y modernidad en Oriente. Política y cultura, (28), 133-155.

View in (Google Scholar)

2. Benlabbah, F. (2008). Islam y derechos de la mujer en Marruecos. cadernos pagu, (30), 95-106.

View in (Google Scholar)

3. Torres Falcón, M. (2005). Género y discriminación. El cotidiano, (134).

View in (Google Scholar) (PDF)

4. Horbath, J. E., \& Gracia, M. A. (2012). La evaluación educativa en México: una propuesta de indicadores de tercera generación para valorar procesos y resultados. Revista temas de coyuntura, (64-65).

View in (Google Scholar)

5. Cepeda, J. P. (2012). Eloy Alfaro, pensamiento y políticas sociales.

View in (Google Scholar)

6. Constituyente, E. A. (2008). Constitución de la República del Ecuador.

View in (Google Scholar)

7. ONU. (2018). Las mujeres y la democracia. Consultado el día 3 de marzo de 2018.

View in (Journal)

8. S. Montaño. (2008). Ni una más. Pensamiento Iberoamericano 2. (In)Seguridad y violencia en América Latina: un reto para la democracia.

View in (PDF)

9. CNE. (2014). Indicadores de participación política de la mujer ecuatoriana.

View in (PDF)

10.CNE. (2014). CNE presenta, Indicadores de Participación Política de la Mujer Ecuatoriana-Elecciones Seccionales.

View in (PDF)

11. CPCCS. (2014). Consejos barriales. Guía metodológica de trabajo barrios y parroquias," Metodología: Consejo de Participación Ciudadana y Control Social.

View in (PDF)

12. UNESCO. (2018). Código Organico de Organización Territorial, Atonomía y Descentralización. Consultado el 5 de marzo de 2018.

View in (PDF)

13. Presidencia de la República. (2010). Código Orgánico Organización Territorial Autonoma Descentralización (COOTAD). Registro Oficial Suplemento 303 de 19-oct-2010.

View in (PDF) 
14. Bareiro, L., Soto, C., \& Soto, L. (2007). La inclusión de las mujeres en los procesos de reforma política en América Latina. Inter-American Development Bank.

View in (Google Scholar)

15. Rodríguez, A. J. (2012). Construir desde las fortalezas: trabajo social y resiliencia. Miscelánea Comillas. Revista de Ciencias Humanas y Sociales, 70(136), 5-36.

View in (Google Scholar)

16. Moreira Moreira, S. C., \& Vinces Garcia, J. G. (2015). El trabajador social y su labor en las unidades educativas fiscales y particulares de la ciudad de portoviejo, 2014 (doctoral dissertation, tatiana moreira chica).

View in (Google Scholar)

17. Casas, G., \& Campos, I. (1999). El enfoque de la resilencia en el trabajo social. Revista Costarricense de Trabajo Social, (9).

View in (Google Scholar)

18. Meza, A. K. T., Freyre, J. R. A., Cevallos, M. G. O., \& Pico, M. J. M. (2018). Autonomy, Good Humor and Support Networks, Potential of Community Resilience Intervention in People Victims of the Earthquake in the Calderón Parish. International Research Journal of Management, IT and Social Sciences (IRJMIS), 5(1), 1-8.

View in (Google Scholar)

19. Macías, E. I. P., Cedeño, H. A. C., \& Chávez, G. M. R. (2018). Importance of Improving Resilience in TeachingLearning Process of Students with Disabilities. International Research Journal of Management, IT and Social Sciences (IRJMIS), 5(2), 120-128.

View in (Google Scholar)

20.Zambrano, R. L. B., Villamil, K. V. S., \& Cantos, K. L. G. (2018). Resilience and Personal Improvement of Students with Motor Disabilities. International Research Journal of Management, IT and Social Sciences (IRJMIS), 5(2), 96-103.

View in (Google Scholar)

Zambrano, M., Barreto, M., \& Chica, T. (2018). Intervention of social work in political participation of women in forming process of neighborhood councils of canton portoviejo. International Journal Of Social Sciences And Humanities (IJSSH), 2(1), 134-146. doi:10.29332/ijssh.v2n1.104 


\section{Biography of Authors}

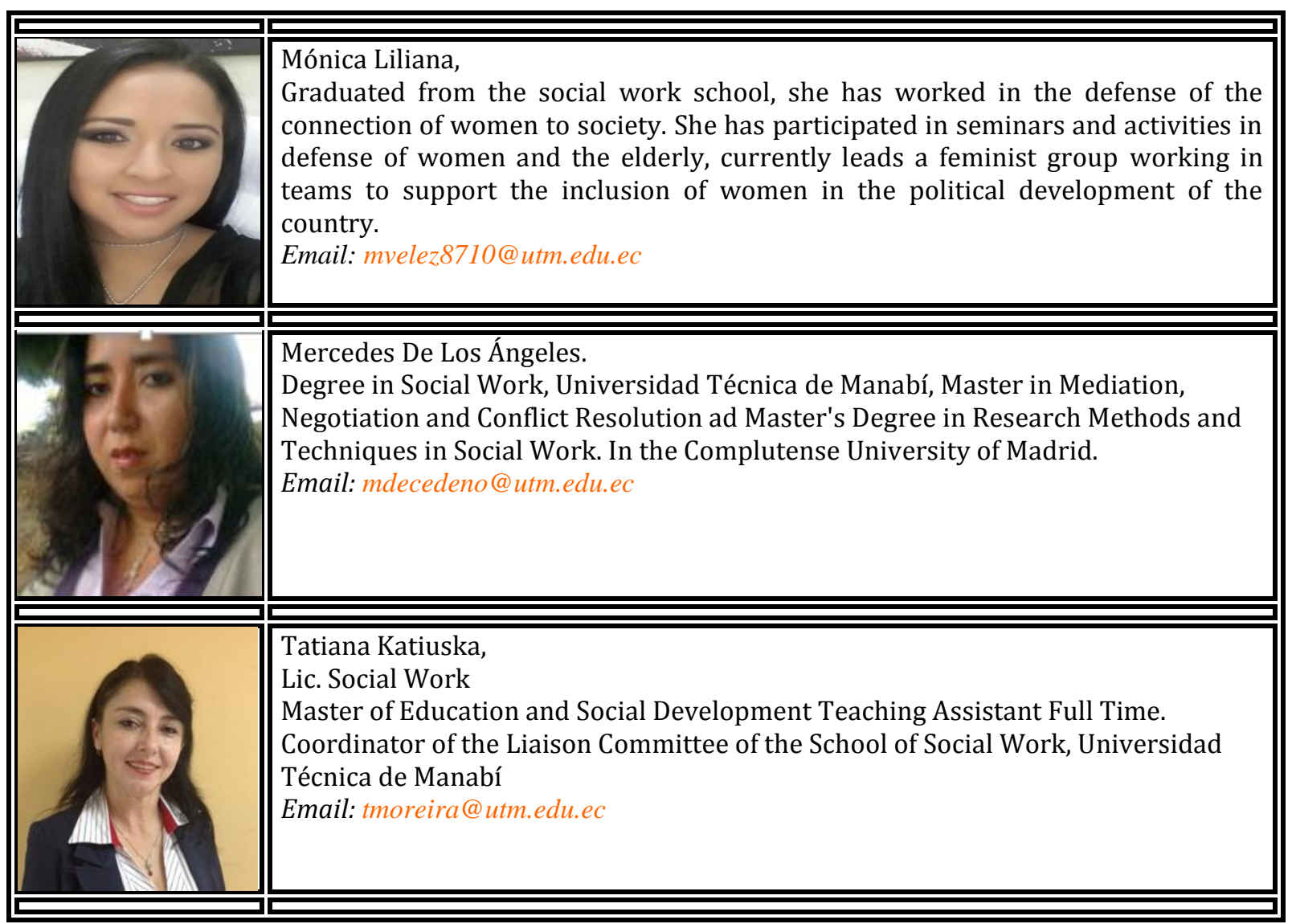

